\title{
Neuroimaging Findings in Patients with Idiopathic Intracranial Hypertension after Treatment
}

\author{
İdiyopatik İntrakraniyal Hipertansiyon Olgularında Tedavi Sonrası \\ Nörogörüntüleme Bulguları
}

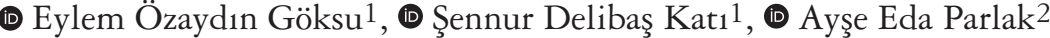 \\ 1 University of Health Sciences Turkey, Antalya Training and Research Hospital, Clinic of Neurology, Antalya, Turkey \\ 2University of Health Sciences Turkey, Antalya Training and Research Hospital, Clinic of Radiology, Antalya, Turkey
}

\begin{abstract}
Objective: Few reports have investigating the reversal of neuroimaging findings of idiopathic intracranial hypertension (IIH). Our study aimed to show to what extent these findings are reversible after treatment.

Materials and Methods: Eight patients with magnetic resonance imaging (MRI) findings who were followed-up in the University of Health Sciences Turkey, Antalya Training and Research Hospital Headache Outpatient Clinic and diagnosed as having IIH between 2017 and 2019 were included in the study. Demographic characteristics of the patients, body mass indexes (BMI), duration of treatment, the timing of MRI taken after treatment, and MRI before and after treatment were recorded.

The sellar configurations were measured on midsagittal T1 images and the height of the midsagittal pituitary gland was measured on T1 or T2 sagittal images. Optic nerve (ON) thickness was measured from T2 axial sections in brain MRI. The Globus configuration was evaluated using diffusion-weighted imaging (DWI) for ON hyperintensity using axial FLAIR images. ON tortuosity was evaluated in T2 images of horizontal sections.

Results: The mean age was 36 [minimum ( $\min ): 22$, maximum (max): 45 ] years, the average BMI was $31.8 \pm 2.8$. All patients were women. Post-treatment MRI was performed after an average of 5.5 (min: 3, max: 10) months later. After the treatment, a partial sella image was detected in one patient with empty sella, and empty sella was observed in one patient with partial sella. The mid sagittal pituitary gland height decreased after treatment in all patients except one. ON thickness improved for both eyes (right eye $\mathrm{p}=0.041$, left eye $\mathrm{p}=0.012$ ). The Globus configuration before and after treatment was the same in all patients. The ON tortiosity improved in one patient, and became clear in one patient. The ON hyperintensity observed in DWI persisted in all patients.
\end{abstract}

Conclusion: Despite the small sample size, this study showed that many of these MRI findings are somewhat reversible after treatment.

Keywords: Idiopathic intracranial hypertension, pseudotumor cerebri, neuroimaging findings

Öz

Amaç: İdiyopatik intrakraniyal hipertansiyonunun (İ̈H) nörogörüntüleme bulgularının geri dönüşümünü araştıran az sayıda çalışma vardır. Çalışmamız, bu bulguların tedavi sonrasında ne derece geri dönüşlü olduğunu göstermeyi amaçlamıştır.

Gereç ve Yöntem: Sağlık Bilimleri Üniversitesi, Antalya Eğitim ve Araştırma Hastanesi Baş Ağrısı Polikliniği’nde takipli, 2017-2019 yılları arasından İïH tanısı konmuş ve manyetik rezonans görüntüleme (MRG) bulguları olan 8 hasta çalışmaya dahil edildi. Hastaların demografik özellikleri, vücut kitle indeksleri (VKI), tedavi süresi, tedaviden ne kadar sonra MRG çekildiği, tedavi öncesi ve sonrası MRG'leri kayıt edildi.

Sellar konfigürasyonlar midsagittal T1 görüntülerde ve midsagittal hipofiz bezinin yüksekliği T1 veya T2 sagittal görüntülerde ölçüldü. Optik sinir (OS) kalınlığı beyin MRG'de T2 aksiyel kesitlerden ölçüldü. Globus konfigürasyonu, aksiyal FLAIR görüntüleri kullanılarak ve OS hiperintensitesi diffüzyon ağırlıklı görüntüleme (DAG) ile değerlendirildi. OS tortiozitesi horizontal kesitlerin T2 görüntülerinde değerlendirildi.

Bulgular: Ortalama yaş 36 [minimum (min): 22, maksimum (maks): 45] ve ortalama VKİ 31,8 2 2,8 idi. Tüm hastalar kadındı. Tedavi sonrası MRG ortalama 5,5 ay sonra çekilmişti (min: 3, maks:10 ay sonra). Boş sellası olan 1 hastada tedavi sonrası parsiyel sella görüntüsü tespit edilirken parsiyel sellası olan 1 hastada

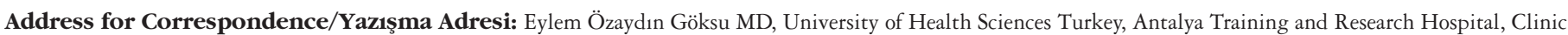
of Neurology, Antalya, Turkey

Phone: +90 5054691758 E-mail: eylemozaydin@hotmail.com ORCID: orcid.org/0000-0001-8851-3094

Received/Geliş Tarihi: 08.10.2020 Accepted/Kabul Tarihi: 03.01.2021

This study will be presented online as a verbal presentation at the global migraine and pain summit $4^{\text {th }}$ MENA meeting and $2^{\text {nd }}$ Turkish African Meeting of headache and pain management (28-31 October 2020).

${ }^{\circ}$ Copyright 2021 by Turkish Neurological Society

Turkish Journal of Neurology published by Galenos Publishing House. 


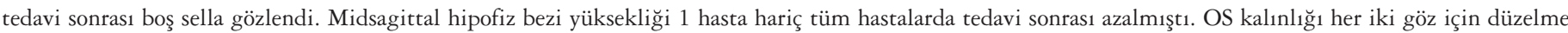

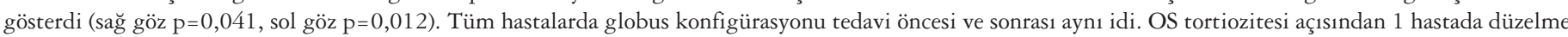
gözlenirken 1 hastada belirginleşme gözlendi. Tüm hastalarda DAG'de gözlenen OS hiperintensitesi devam etmekteydi.

Sonuç: Hasta sayımız az olsa da, çalışmamız bu MRG bulgularının birçoğunun tedaviden sonra bir dereceye kadar geri dönüşümlü olduğunu göstermiştir.

Anahtar Kelimeler: İdiyopatik intrakraniyal hipertansiyon, psödotümör serebri, nörogörüntüleme bulguları

\section{Introduction}

Idiopathic intracranial hypertension (IIH), which is also called benign intracranial hypertension or pseudotumor cerebri, is characterized by high intracranial pressure occuring without any identifiable causal factor. The exact cause is still unclear. IIH often affects young, obese women of childbearing age. The incidence in overweight young adult women is $15-19$ cases per 100,000 people in the United States. Its incidence has tended to increase with increasing obesity in the world because IIH is associated with obesity $(1,2,3,4,5)$. The clinical syndrome was initially established with the Dandy criteria. It has undergone various modifications to include imaging findings such as computed tomography and magnetic resonance imaging (MRI) and is now defined in the Headache Classification of the International Headache Association $(6,7)$. The most common symptoms of IIH include headache (94\%), transient blurred vision (68\%), pulse-related tinnitus (58\%), photopsy (54\%), and retrobulbar pain (44\%) (8). Diagnosis includes neuroimaging techniques to exclude secondary causes of high intracranial pressure and to show increased intracranial pressure. In these patients, the diagnosis may be largely dependent on MRI. Reported MRI findings that may aid the diagnosis of IIH include empty sella, posterior globe flattening, optic nerve $(\mathrm{ON})$ tortuosity, ON sheath distension, and transverse sinus stenosis $(9,10)$.

Although the neuroimaging findings showing $\mathrm{IIH}$ are well established, few reports have investigated the reversibility of these features. Our study aimed to show how reversible such MRI findings were after treatment.

\section{Materials and Methods}

Eight patients who were followed up in the University of Health Sciences Turkey, Antalya Training and Research Hospital Headache Outpatient Clinic, diagnosed as having IIH according to modified Dandy criteria between 2017 and 2019, had MRI findings before and after treatment, and whose clinical treatment was discontinued due to improvement, were included in the study. Approval was obtained from the Ethics Committee of University of Health Sciences Turkey, Antalya Training and Research Hospital (date: 2.3.2020, decision no: 4/12). Informed consent was obtained from all patients. Demographic characteristics of patients, pre- and post-treatment MRIs, body mass index (BMI), cerebrospinal fluid (CSF) opening pressure, duration of treatment, and time of MRI performed after treatment were recorded. Routine brain MRI, pituitary MRI, and orbital MRI were evaluated comprehensively by a single experienced neuroradiologist.

Sellar configuration, one of the MRI findings, was evaluated on midsagittal T1 images and classified as normal, partially empty sella, and empty sella (Figure 1). The height of the midsagittal pituitary gland was measured on $\mathrm{T} 1$ or $\mathrm{T} 2$ sagittal images (Figure 2). ON thickness was measured on T2 axial sections in brain MRI.
Globus configuration was classified as normal, flattened sclera, and prominent $\mathrm{ON}$ head protrusion, using the axial FLAIR images. ON hyperintensity was evaluated using diffusion-weighted imaging (DWI). ON tortuosity were evaluated on T2 images, horizontally (Figure 3).

\section{Statistical Analysis}

Statistical analysis was performed using the SPSS version 23 software. The normal distribution of the variables was examined using visual (histogram and probability graphics) and analytical methods (Kolmogorov-Smirnov). Descriptive analyses are given using the median and interquartile for variables that were not

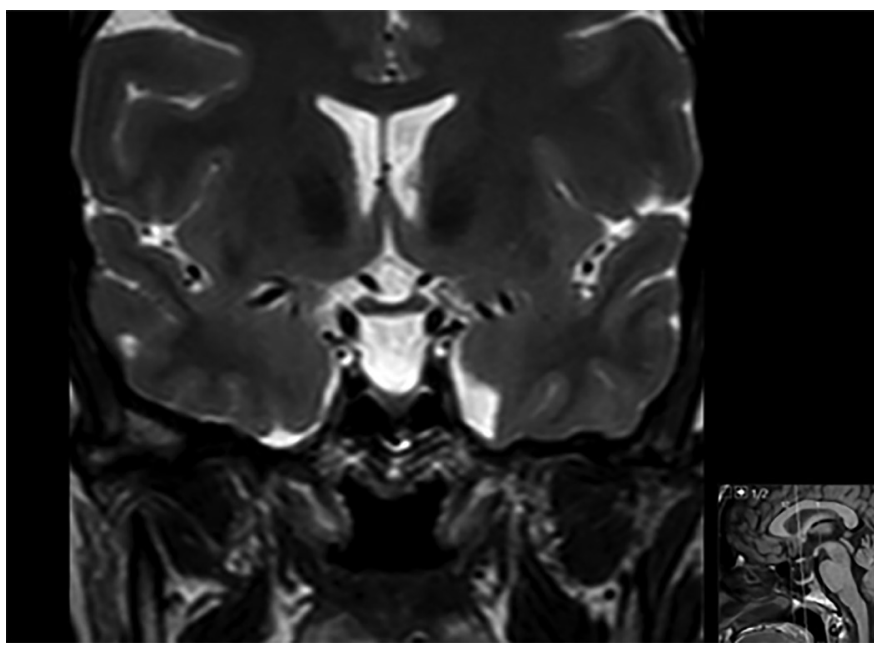

Figure 1. Empty sella

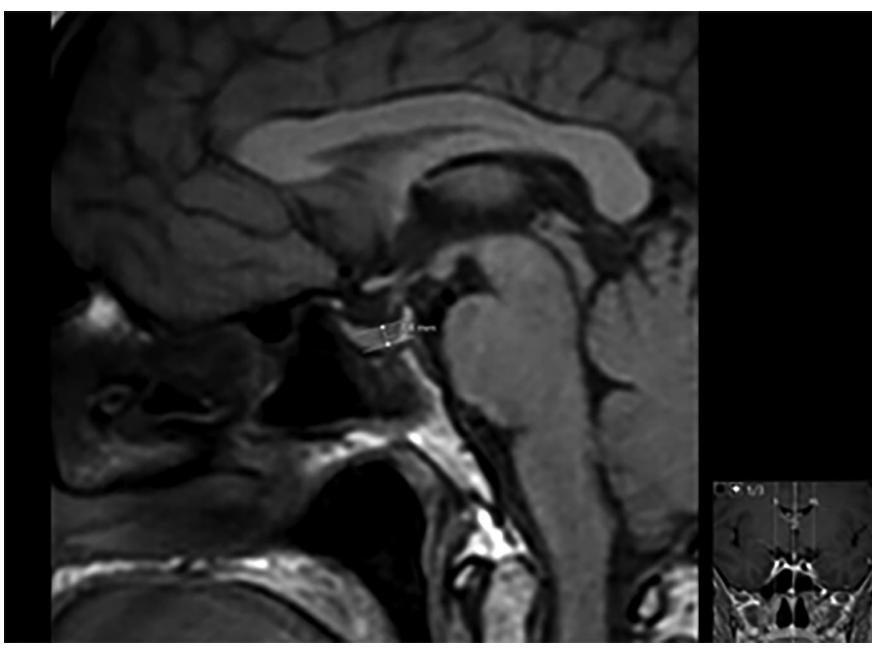

Figure 2. Measurement of pituitary gland height 
normally distributed. Variables were compared using the Wilcoxon test because they did not show normal distribution, and $\mathrm{p}<0.05$ was considered statistically significant.

\section{Results}

The average age of the eight patients included in the study was 36 [(minimum (min): 22, maximum (max): 45] years and all patients were female. All of the patients, with a mean BMI of $31.8 \pm 2.8 \mathrm{~kg} / \mathrm{m}^{2}$ were overweight. The treatment period was 17.5 months on average, the dose range of acetazolamide used was 750 $1,500 \mathrm{mg}$, and the mean time to perform MRI after treatment was 5.5 (min: 3, max: 10) months later. Before treatment, the sellar configuration was normal in four patients, partial empty sella in three patients, and empty sella in one patient. Partial empty

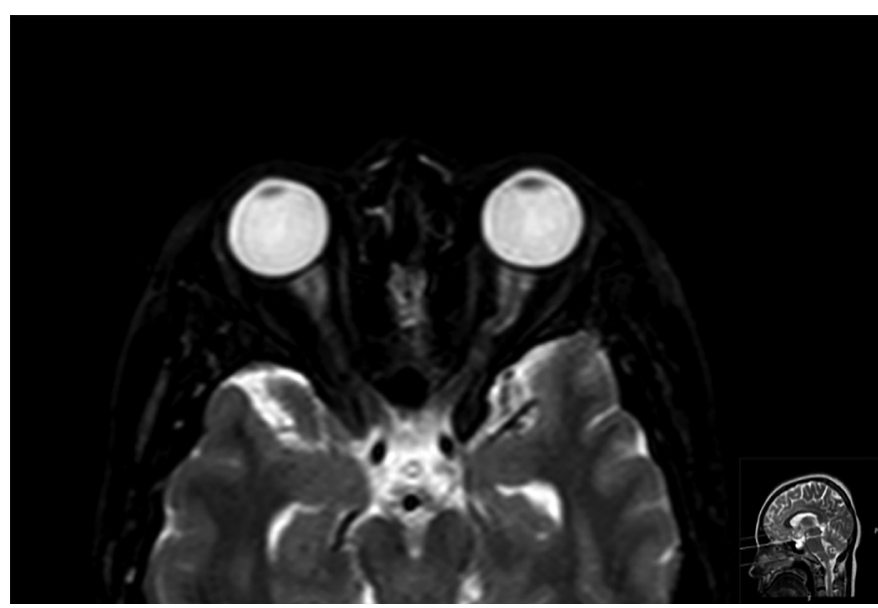

Figure 3. Optic nerve tortuosity sella was detected after treatment in the patient who had empty sella before, and empty sella was observed after treatment in a patient who had partial empty sella before. Midsagittal pituitary gland height decreased after treatment in all patients except one $(\mathrm{p}=0.16)$. ON thickness improved after treatment in both eyes $(4.5 \pm 0.94$ before treatment and $3.5 \pm 0.93$ after treatment for the right eye, $\mathrm{p}=0.041$ ), and $5 \pm 0.58$ before treatment and $3.6 \pm 0.67$ after treatment for the left eye, $\mathrm{p}=0.012$ ).

In terms of globus configuration, pre-treatment and posttreatment MRI characteristics of all patients were the same. ON tortuosity improved in one patient after treatment and worsened in one patient after treatment. No change was observed in other patients. Hyperintensity in DWI-weighted imaging was observed in all patients before treatment and persisted after treatment. The MRI findings of the patients are shown in Table 1.

In subsequent follow-ups, it was found that symptoms recurred in three of the patients after 3, 4, and 12 months of the treatment. The patients could not be evaluated in terms of previous MRI findings because they did not undergo repeat MRIs.

\section{Discussion}

In our study, in patients with IIH whose drug treatment was discontinued because of the improvement of clinical symptoms and papillary edema, ON thickness significantly reduced. Although an improvement was observed in the height of the midsagittal pituitary gland, it was not statistically significant.

Although empty sella is the oldest and most frequently reported neuroimaging finding in patients with $\mathrm{IIH}$, it is a nonspecific finding, and it has been hypothesized that cumulative CSF pressure causes sellar restructuring starting from the subclinical stages of IIH $(11,12)$. In a study conducted by Chang et al. (13) in 2016, similar to our study, although they showed a possible

Tablo 1. Magnetic resonance imaging findings

\begin{tabular}{|c|c|c|c|c|c|c|c|c|c|c|c|c|c|}
\hline \multirow{2}{*}{ Patients } & \multirow{2}{*}{ Age } & \multicolumn{4}{|c|}{ Optic nerve tortuosity } & \multicolumn{4}{|c|}{ Optic nerve thickness (mm) } & \multicolumn{2}{|c|}{$\begin{array}{l}\text { Sellar } \\
\text { configuration }\end{array}$} & \multicolumn{2}{|c|}{$\begin{array}{l}\text { Midsagittal pituitary } \\
\text { gland height }(\mathrm{mm})\end{array}$} \\
\hline & & $\begin{array}{l}\text { BT } \\
\text { L eye }\end{array}$ & $\begin{array}{l}\text { AT R } \\
\text { eye }\end{array}$ & $\begin{array}{l}\text { BT L } \\
\text { eye }\end{array}$ & $\begin{array}{l}\text { AT L } \\
\text { eye }\end{array}$ & $\begin{array}{l}\text { BT } \\
\text { R eye }\end{array}$ & $\begin{array}{l}\text { AT } \\
\text { R eye }\end{array}$ & $\begin{array}{l}\text { BT L } \\
\text { eye }\end{array}$ & $\begin{array}{l}\text { AT L } \\
\text { eye }\end{array}$ & BT & AT & BT & $\mathrm{AT}$ \\
\hline 1. SC & 36 & - & - & + & + & 4.5 & 3.5 & 5.0 & 3.6 & $\begin{array}{l}\text { Empty } \\
\text { sella }\end{array}$ & $\begin{array}{l}\text { Partial } \\
\text { empty } \\
\text { sella }\end{array}$ & 1 & 1.5 \\
\hline 2. EK & 42 & + & - & + & + & 5.4 & 5.6 & 5.1 & 4.6 & Normal & Normal & 2.8 & 2.9 \\
\hline 3. SE & 36 & - & - & - & - & 4.6 & 4.3 & 4.3 & 4.1 & Normal & Normal & 4.8 & 5.2 \\
\hline 4. SA & 22 & - & - & - & + & 4.3 & 4.3 & 4.9 & 4.7 & Normal & Normal & 3.0 & 3.1 \\
\hline 5. SÇ & 45 & - & - & + & + & 4.5 & 3.5 & 5.0 & 3.6 & $\begin{array}{l}\text { Partial } \\
\text { empty } \\
\text { sella }\end{array}$ & $\begin{array}{l}\text { Partial } \\
\text { empty } \\
\text { sella }\end{array}$ & 2.8 & 3.0 \\
\hline 6. FG & 38 & - & - & + & + & 3.5 & 3.3 & 4.2 & 3.6 & Normal & Normal & 3.3 & 4.6 \\
\hline 7. SS & 32 & + & - & + & - & 4.2 & 3.1 & 5.0 & 3.2 & $\begin{array}{l}\text { Partial } \\
\text { empty } \\
\text { sella }\end{array}$ & $\begin{array}{l}\text { Partial } \\
\text { empty } \\
\text { sella }\end{array}$ & 2.0 & 2.3 \\
\hline 8. MD & 31 & - & - & + & + & 6.4 & 2.5 & 6.2 & 2.7 & $\begin{array}{l}\text { Partial } \\
\text { empty } \\
\text { sella }\end{array}$ & $\begin{array}{l}\text { Empty } \\
\text { sella }\end{array}$ & 2.5 & 1.0 \\
\hline
\end{tabular}


improvement tendency in the sellar configuration, no statistical significance was found. In our study, an improvement was observed in one patient and worsening was observed in one patient, no change was detected in the others.

Hoffmann et al. (14) accepted the cut-off value of the pituitary height of patients with $\mathrm{IIH}$ as $4.80 \mathrm{~mm}$ (sensitivity $88.0 \%$, specificity $69.57 \%$, accuracy $82.0 \%$ ) and found that it was significantly reduced in the patient group compared with controls. Ranganathan et al. (15) found that the area and height of the pituitary gland increased in patients with IIH after treatment, and based on this, they suggested that the pituitary gland was not compressed, but rather deformed, and that filling of the suprasellar cistern created an empty sella. In the study conducted by Batur Caglayan et al. (16) in 2019, the height of the pituitary gland in patients before and after treatment was found to be significantly lower than in healthy controls, but even though an improvement was observed after months of treatment, they still found it lower than in the control group. In our study, midsagittal pituitary gland height increased in all patients except one after treatment, but there was no statistically significant difference.

The normal convexity of the posterior sphere reflects the balance between intracranial and intraocular pressure $(16,17)$. Previous studies reported that this MRI finding was highly specific but not sensitive to IIH. Nevertheless, Agid et al. $(18,19)$ found that flattening of the sclera was the only sign that definitively reflected IIH. In another study designed as a before and after treatment study, the high specificity of the globus configuration was confirmed and also it was shown that it improved after treatment (16). In our study, similar to the study of Chang et al. (13), no change was observed in the patients in terms of the globus configuration before and after treatment. This might be due to the low number of patients and the absence of orbital MRI in all our patients.

The ON sheath is relatively flexible, so it responds to changes as expansion in the presence of increased pressure. The diameter of the $\mathrm{ON}$ sheath decreased in cerebral hypovolemia, but it increased in patients with IIH. Increased cerebral pressure and ON sheath diameter were found to be strongly associated with IIH in adults (20). Increase in ON sheath thickness is among the most common MRI findings in IIH (21). In previous studies, it was shown that the mean ON sheath diameter decreased after IIH treatment, but remained higher than in healthy controls $(13,16)$. Although we could not measure the $\mathrm{ON}$ sheath diameter clearly in our study because not all patients had orbital MRIs before and after treatment, ON thickness measurement performed on brain MRIs increased before treatment in all our patients, and it decreased significantly after treatment in both eyes.

ON hyperintensity assessed by DWI-weighted imaging is a reliable and highly specific marker of papilledema (22). However, Salvay et al. (23) found no relationship between lowergrade papilledema and $\mathrm{ON}$ hyperintensity. In our study, ON hyperintensity in DWI-weighted imaging, which was detected in all patients, persisted after treatment in all patients.

Twisting of the ON observed in the sagittal and axial planes is defined as the tortuosity of ON. Horizontal or vertical bending is associated with stretching of the $\mathrm{ON}$ sheath between the proximal and distal fixation points. Although the sensitivity of this MRI finding is not high, it has been reported that horizontal tortuosity is more specific to IIH than vertical tortuosity $(17,24,25)$. In the study of Batur Caglayan et al. (16), the frequency of horizontal tortuosity was found to be significantly higher in the pretreatment IIH group compared with the control group; however, no difference was found between the post-treatment IIH group and control group. This finding suggested that horizontal tortuosity was an indicator of $\mathrm{IIH}$ in the pre-treatment group, but it was not a valuable follow-up indicator. In our study, although ON tortuosity improved in one patient after treatment and became apparent in one patient after treatment, no change was observed in the other patients.

\section{Study Limitations}

Not all patients had orbital MRI and MR venography in this retrospectively designed study, which is a limitation of the study.

\section{Conclusion}

Despite the small sample size, this study showed that MRI findings, especially midsagittal pituitary gland height and ON sheath thickness measurements, were to some extent reversible after treatment. The limited reversal of MRI findings in posttreatment patients with IIH may be due to possible bone erosion and loss of flexibility of anatomic structures over time. To detect changes in neuroimaging findings before and after treatment, prospective studies with larger sample sizes are needed.

\section{Ethics}

Ethics Committee Approval: Ethics Committee of University of Health Sciences Turkey, Antalya Training and Research Hospital (date: 2.3.2020, decision no: 4/12).

Informed Consent: Informed consent was obtained from all patients.

Peer-review: Externally peer-reviewed.

\section{Authorship Contributions}

Concept: E.Ö.G., Design: E.Ö.G., A.E.P., Data Collection or Processing: E.Ö.G., Ş.D.K., A.E.P., Analysis or Interpretation: E.Ö.G., S..D.K., A.E.P., Literature Search: E.Ö.G., Ş.D.K., Writing: E.Ö.G.

Conflict of Interest: The authors have not declared any conflict of interest related to this article.

Financial Disclosure: No financial support was received from any institution or person for our study.

\section{References}

1. Ball AK, Clarke CE. Idiopathic intracranial hypertension. Lancet Neurol 2006;5:433-442.

2. McGeeney BE, Friedman DI. Pseudotumor cerebri pathophysiology. Headache 2014;54:445-458.

3. Durcan FJ, Corbett JJ, Wall M. The incidence of pseudotumor cerebri. Population studies in Iowa and Louisiana. Arch Neurol 1988;45:875-877.

4. Rowe FJ, Sarkies NJ. The relationship between obesity and idiopathic intracranial hypertension. Int J Obes Relat Metab Disord 1999;23:54-59.

5. NCD Risk Factor Collaboration (NCD-RisC). Trends in adult body-mass index in 200 countries from 1975 to 2014: A pooled analysis of 1698 population-based measurement studies with 19.2 million participants, Lancet 2016;387:1377-1396

6. Headache Classification Subcommittee of the International Headache Society. The International Classification of Headache Disorders: 2nd ed. Cephalalgia 2004;24(Suppl 1):9-160.

7. Friedman DI, Jacobson DM. Diagnostic criteria for idiopathic intracranial hypertension. Neurology 2002;59:1492-1495. 
8. Wall M. Idiopathic intracranial hypertension. Neurol Clin 2010;28:593617.

9. Kwee RM, Kwee TC. Systematic review and meta-analysis of MRI signs for diagnosis of idiopathic intracranial hypertension. Eur J Radiol 2019;116:106-115.

10. Friedman DI, Liu GT, Digre KB. Revised diagnostic criteria for the pseudotumor cerebri syndrome in adults and children. Neurology 2013;81:1159-1165

11. Foresti M, Guidali A, Susanna P. Primary empty sella. Incidence in 500 asymptomatic subjects examined with magnetic resonance. Radiol Med 1991;81:803-807.

12. Yuh WT, Zhu M, Taoka T, et al. MR imaging of pituitary morphology in idiopathic intracranial hypertension. J Magn Reson Imaging 2000;12:808813.

13. Chang RO, Marshall BK, Yahyavi N, et al. Neuroimaging features of idiopathic intracranial hypertension persist after resolution of papilloedema. Neuroophthalmology 2016;40:165-170.

14. Hoffmann J, Huppertz HJ, Schmidt C, et al. Morphometric and volumetric MRI changes in idiopathic intracranial hypertension. Cephalalgia 2013;33:1075-1084

15. Ranganathan S, Lee SH, Checkver A, et al. Magnetic resonance imaging finding of empty sella in obesity related idiopathic intracranial hypertension is associated with enlarged sella turcica. Neuroradiology 2013;55:955-961.

16. Batur Caglayan HZ, Ucar M, Hasanreisoglu M, Nazliel B, Tokgoz N. Magnetic resonance imaging of idiopathic intracranial hypertension. J Neuroophthalmology 2019;39:324-329.
17. Bidot S, Saindane AM, Peragallo JH, et al. Brain imaging in idiopathic intracranial hypertension. J Neuroophthalmol 2015;35:400-411.

18. Kyung SE, Botelho JV, Horton JC. Enlargement of the sella turcica in pseudotumor cerebri. J Neurosurg 2014;120:538-542.

19. Agid R, Farb RI, Willinsky RA, Mikulis DJ, Tomlinson G. Idiopathic intracranial hypertension: the validity of crosssectional neuroimaging signs. Neuroradiology 2006;48:521-527.

20. Hirfanoglu T, Aydin K, Serdaroglu A, Havali C. Novel magnetic resonance imaging findings in children with intracranial hypertension. Pediatr Neurol 2015;53:151-156.

21. Wong H, Sanghera K, Neufeld A, Maxner C, Shankar JJS. Clinicoradiological correlation of magnetic resonance imaging findings in patients with idiopathic intracranial hypertension. Neuroradiology 2020;62:49-53.

22. Viets R, Parsons M, Van Stavern G, Hildebolt C, Sharma A. Hyperintense optic nerve heads on diffusion-weighted imaging: a potential imaging sign of papilledema. AJNR Am J Neuroradiol 2013;34:1438-1442.

23. Salvay DM, Padhye LV, Huecker JB, et al. Correlation between papilledema grade and diffusion-weighted magnetic resonance imaging in idiopathic intracranial hypertension. J Neuroophthalmol 2014;34:331-335.

24. Passi N, Degnan AJ, Levy LM. MR imaging of papilledema and visual pathways: effects of increased intracranial pressure and pathophysiologic mechanisms. AJNR Am J Neuroradiol 2013;34:919-924.

25. Görkem SB, Doganay S, Canpolat M, et al. MR imaging findings in children with pseudotumor cerebri and comparison with healthy controls. Childs Nerv Syst 2015;31:373-380. 